\title{
Physical and microbiological properties of alluvial calcareous Çumra province soils (Central Anatolia, Turkey)
}

\section{Ahmet Sami Erol a, Evgeny Shein b,*, Evgeny Milanovskiy b, Fariz Mikailsoy c, Fatih Er a, Sabit Ersahin d}

\author{
a Selçuk University, Çumra Vocaitonal School, Çumra, Konya, Turkey \\ b Moscow State University, Faculty of Soil Science, Moscow, Russia \\ c Iğdır University, Faculty of Agriculture, Department of Soil Science and Plant Nutrition, Iğdır, Turkey \\ b Moscow State University, Faculty of Soil Science, Moscow, Russia \\ b Çankırı Karatekin University, University, Faculty of Forestry, Çankırı, Turkey
}

\section{Article Info}

Received : 01.07.2014

Accepted : 01.02.2015

\begin{abstract}
Alluvial calcareous soils in Central Anatolia (Konya province, Çumra district) has a heavy granulometric composition (average clay), low organic carbon content (less than 1\%), but stable pore space structure and favorable agrophysical properties. Studies of the water regime in drip irrigation confirm favorable hydrological properties of these soils. It is assumed that the favorable structure of the pore space due to vigorous activity a large and diverse soil biota. Four phyla dominate in soil biota, among which predominate Actinobacteria. The higher (Streptomyces), and lower (three species Rhodococcus) actinobacteria are predominant in large amounts as a part of this phyla. Large biodiversity at a sufficiently high bacteria richness formed the structure of the microbial community that contribute to the balanced production of specific metabolites, including gases ( $\mathrm{CO} 2, \mathrm{~N} 2)$, which allows the soil to function actively, preventing compaction of the pore space and maintaining optimal density, porosity, hydrologic properties of the studied silty clay soils.
\end{abstract}

Keywords: soil physics, pore space, mineralogical composition, microbiological composition, agrophysics

(C) 2015 Federation of Eurasian Soil Science Societies. All rights reserved

\section{Introduction}

Soils of Central Anatolia are actively used in agriculture due to their high heat resources, natural fertility, and the availability of water for their irrigation. However, many processes that determine the evolution and contribute to the scientifically substantiated and ecologically safe use of these soils remain poorly unknown. No scientific works on the optimization of the water and heat regimes of these soils have been carried out, although it is evident that such works are necessary to elaborate a strategy for the agricultural production and the rational use of the natural resources. Therefore, the agrophysical assessment of the soils in this region is very important. Moreover, the mineralogy of these soils were not studied, but it is well-known that the granulometric and mineralogical compositions are determined the main hydrological and agrophysical properties. This work is aimed at studying the physical properties, the elements of the water regime, and the soil microbiota of the alluvial calcareous soils by a field experiment.

\footnotetext{
${ }^{*}$ Corresponding author.

Moscow State University, Faculty of Soil Science, Department of Soil Physics and Reclamation, Moscow, 119991 Russia

Tel.: +74959393684

E-mail address: evgeny.shein@gmail.com

ISSN: $2147-4249$
} 
The objectives of this research were: (1) to investigate the basic physical properties, (2) to study the mineralogical composition, (3) to Assess agrophysical properties using different criteria, and (4) to characterize the microbial community of the these calcareous alluvial soils.

\section{Material and Methods}

The Çumra region (approximately 172 thousand ha) is located in the central part of Turkey (Central Anatolia, Konya province) between $37^{\circ}$ and $38^{\circ} \mathrm{E}$ and $33^{\circ}$ and $34^{\circ} \mathrm{N}$ at an altitude of $1013 \mathrm{~m}$ a.s.l. (Figure 1). It comprises sloping highlands and level areas such as plains. In the plains, agriculture has been maintained for a long time. The climate is principally continental with hot and dry summers and cold and dry winters. The mean annual temperature is $11.8^{\circ} \mathrm{C}$; the minimum and maximum temperatures are -6 and $+31^{\circ} \mathrm{C}$, respectively. The mean annual precipitation is $306 \mathrm{~mm}$. In recent years, the amount of precipitation has decreased (232.2 $\mathrm{mm}$ ) as compared to that in the previous (2000-2012) years (Figure 2).

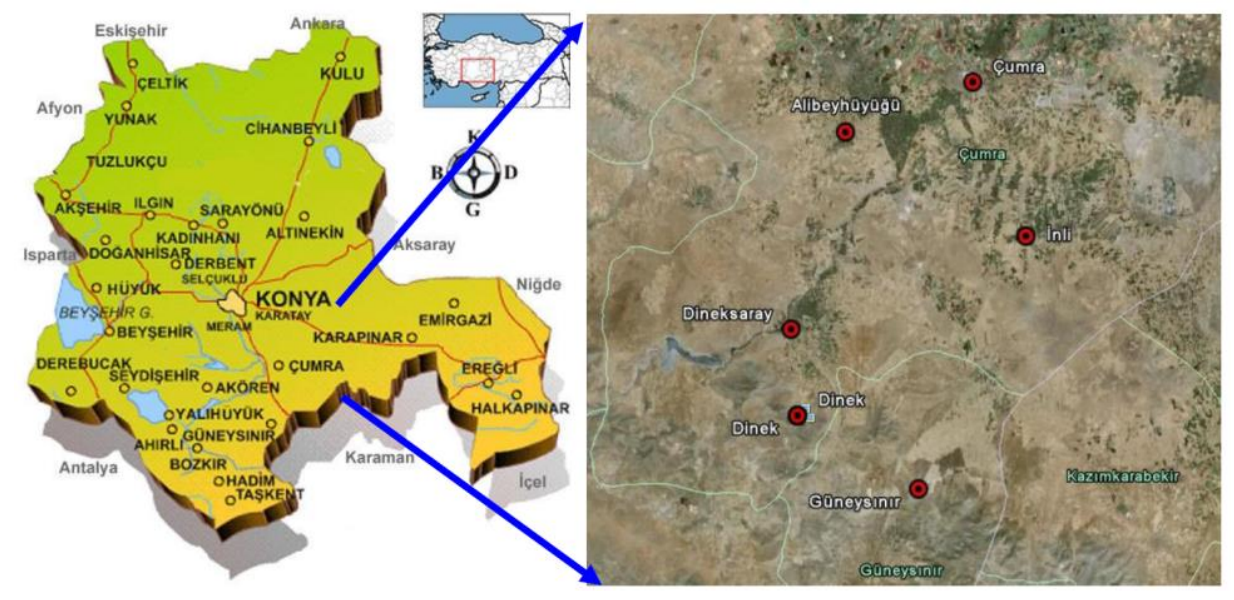

Figure 1. Map the of study area in Çumra Province
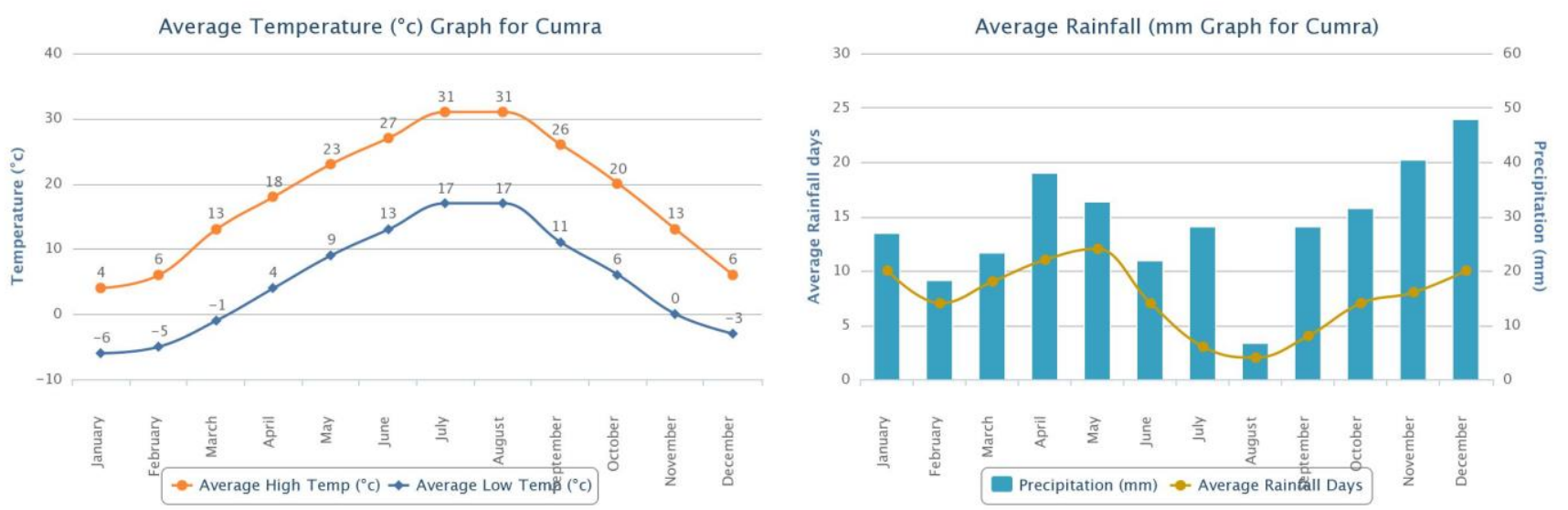

Figure 2. Long-term climatic data for Çumra, Konya, Turkey

In the study area (Agricultural Faculty of Selcuk University, Konya), seven soil profiles were excavated, apart from 25-30 m one to another. Drop irrigation was applied during the study.

Particle-size distribuiton was determined using the laser diffraction method and a FRITSCH Analysette 22 device with the preliminary treatment of the samples with ultrasound in pure water (Shein et al., 2006, 2014). The soil bulk density was determined by the method of a cutting ring (Shein, 2005). Carbon and $\mathrm{N}$ contents were measured using a CNHS analyzer (Vario EL III Elementar) for solid samples.

Composition of the microbial community was reconstructed according to the microbial markers (fatty acids and their derivatives - fatty hydroxyacids and aldehydes) that were determined after the acid methanolysis of the soil samples using the molecular method of gas chromatography-mass_spectrometry (GCh-MS). The analysis was performed using a GCh-MS system (HP_5973 Agilent Technologies (USA)). This methodology is described in detail in Verkhovtseva et al. (2004) and Shein et al. (2014). 


\section{Results and Discussion}

The studied soils are heavy textured along their profile. According to the international classification, their particle size composition is silty clay ( $44.8 \%$ clay, $54.2 \%$ coarse silt, and $1 \%$ sand), while by the Kachinskiy classification, they are referred to medium clay (Shein, 2005; Shein et al., 2006,2014). At the depth of $40 \mathrm{~cm}$, the soil texture becomes heavier, and the soil density increases. These changes in density and texture would be related to the agricultural practices (compaction of the subsoil by agricultural machines) or to the natural lessivage of fine particles into the deeper layers. It should be emphasized that, despite the heavy texture and low organic matter content, these soils have high porosity and a stable structure and enduring pore geometry. This fact is confirmed by numerous measurements of the filtration coefficient by the method of flood areas. The values of this coefficient are unusually high for heavy textured soils, ranging from 250 to $360 \mathrm{~cm} /$ day. As a rule, the soils of the same texture (light clay-medium clay) are characterized by low (3-7 $\mathrm{cm} /$ day) filtration coefficients if they do not have a well pronounced stable aggregate structure. In the studied soils, there were no agronomically valuable aggregates. At the same time, the results of water permeability tests of the soils showed that, in the first and last hours of the observations, the rate of absorption slightly decreased. The latter is an important and agrophysically valuable property. We think that the reason for the stable favorable agrophysical status of the studied soil is connected with the mineralogical composition of these soils (Table 1).

Table 1. Mineralogical composition of the studied soils and of the fine fractions

\begin{tabular}{lll}
\hline & Mineralogical soil composition & \\
\hline Mineral / horizon, depth, cm & Horizon A, 0-5 & Horizon B, 40-50 \\
\hline Albite & 3,8 & 2,3 \\
Anorthite & 3,3 & 20,9 \\
Illite / Mica & 20,2 & 7,2 \\
Illite-Smectite & 6,6 & 24,3 dominant \\
Calcite & 25,6 & 4,7 \\
Kaolinite & 4,9 & 23,5 \\
Quartz & 24,0 & 1,3 \\
Microcline & 1,1 & 3,2 \\
Orthoclase & 3,6 & 1,9 \\
Smectite & 1,6 & 4,8 \\
Chlorite & 5,3 & 49,5 \\
& Mineralogical composition of the clay fraction \\
\hline Illite / Mica & 43,2 & 30,8 \\
Illite / smectite & 33,2 & 10,7 \\
Kaolin & 10,5 & 4,1 \\
Smectite & 5,9 & 4,9 \\
Chlorite & 7,2 & \\
\hline
\end{tabular}

Illite and micas are principal clay minerals of these soils. These minerals have a very significant impact on soil fertility and the sorption of various substances, including agrochemicals. As it is well known, illites and micas contain potassium ions in their crystal lattice, which is primary natural source of this macronutrient for plant nutrition (Sokolova et al., 2005). And from these minerals potassium ion rapidly diffuses to the soil solutions in the process of weathering, thereby improving soil fertility. However, this does not mean that the investigated soils do not need potash. Despite to the common belief that Turkish soils are rich in $\mathrm{K}, \mathrm{K}$ fertilizers are frequently needed in some localities.

The studied soils are rich in $\mathrm{CaCO}_{3}$. Lime reduce shrinkage and swelling, and prevent cracking in heavy granulometric soils. Lack of distinct processes of swelling and shrinkage leads to the formation of stable porosity of these soils. In turn, stable porosity provides good infiltration and clay composition - high water retention of the soil. All this indicates a favorable water-physical and hydrological properties of soils, due primarily to the predominance of calcite in the gross mineralogical composition and illite-mica in the mineralogical composition of fine fractions.

The results of the total microbiological characterization of the studied soils showed that four phyla predominated the soils. Among them, the Actinobacteria phylum is the principal one. In this phylum, both higher (Streptomyces forming mycelium) and lower (three species of Rhodococcus) actinobacteria were found in high amounts. These species are actinobacteria, for which the main ecological niche is the anaerobic zone of the soils, where they perform the hydrolysis of complex substrates, for instance, the hydrolysis of 
cellulose and even carbohydrates (Shein et al., 2014; Verkhovtseva et al., 2004). In addition, the antibiotic activity of Streptomyces is important in the formation of the microbial community, where Streptomyces act as a factor regulating the composition of the cenosis, which inhibits the development of one species and provides conditions for the reproduction of others. Rhodococcus can produce bioactive steroids and acrylic acid (McLeod et al., 2006). Consequently, the role of these dominating actinobacteria appears to be determined not only by their strong hydrolytic features in relation to complex polymers but also by their capacity to regulate the structure of the soil microbial community. Anaerobic hydrolytics of this phylum are also important. We found Bifidobacterium sp., which was observed in the control soils. This genus is useful for soil fertility, since it has the ability to excrete some enzymes, aminoacids, and regulators of the plant growth. On the whole, the diversity of microorganisms is rather high, we found 47 species of bacteria from 35 genera.

The total number is $10^{7} \mathrm{cell} / \mathrm{g}$ soil. It is worth noting that, at the humus content of $1 \%$, this number of bacteria and their diversity are considered rather high. The $\mathrm{C} / \mathrm{N}$ ratio in the soil is close to that characteristic of microbial cells (6.2), thus showing favorable soil conditions for the development of microorganisms. Probably, the high biodiversity at the great number of bacteria and the developed trophic interrelations in the microbial community promote the balanced production of specific metabolites, including gaseous ones $\left(\mathrm{CO}_{2}, \mathrm{H}_{2}\right)$. This fact allows the clayey soil studied to actively protect the porous space against breaking down and to maintain the optimal bulk density, porosity, and hydrological properties.

\section{Conclusion}

- Some physical (density, saturated conductıvity, particle size composition, etc.), chemical and mineralogical properties of an alluvial calcareous heavy textured (medium clay) soils were studied in Central Anatolia (Konya province, Cumra region). These soils with a low organic carbon content (less than 1\%) have favorable agrophysical properties due to the stable structure of the pore space.

- The favorable structure of the pore space would be enhanced by mineralogical composition, in which calcite $(25.6 \%)$ and illtes-micas are dominated in the fine fraction of about $49 \%$.

- Moreover, high richness and diversity of the microbial community were found in these soils. Four phyla predominate in the microbiological composition of the studied soils; among them, Actinobacteria is the dominant, mediating these clayey soils to function rather actively while protecting the pore space against compaction and maintaining the optimal density, porosity, and hydrological properties.

\section{Acknowledgements}

We thank for the support from Russian fund of basic researches, grant RSCF No 14-16-00065.

\section{References}

McLeod, M.P., Warren, R.L., Hsiao, N., Araki, N., Myhre, M., Fernandes, C.,Miyazawa, D., Wong, W., Lillquist, A.L., Wang, D., Dosanjh, M., Hara, H., Petrescu, A., Morin, R.D., Yang, G., Stott, J.M., Schein, J.E., Shin, H., Smailus, D., Siddiqui, A.S., Marra, M.A., Jones, S.J.M., Holt, R., Brinkman, F.S.L., Miyauchi, K., Fukuda, M., Davies, J.E., Mohn, W.W., Eltis L.D., 2006. The complete genome of Rhodococcus sp. RHA1 provides insights into a catabolic powerhouse. PNAS 103 (42): 15582-15587.

Shein, E.V., 2005. A Course of Soil Physics (Izd. Mosk. Gos. Univ., Moscow) [in Russian].

Shein, E.V., Erol, A.S., Milanovskiy, E.Yu., Verkhovtseva, N.V., Mikayilov, F.D., Er, F., Ersahin, S., 2014. Agrophysical assessment of alluvial calcareous soils of the Cumra Region of Central Anatolia in Turkey. Eurasian Soil Science 47(7): 694-698

Shein, E.V., Milanovskii, E.Yu., Molov, A.Z., 2006. The effect of organic matter on the difference between particle_size distribution data obtained by the sedimentometric and laser diffraction methods. Eurasian Soil Science 39 (S1): 84-90.

Sokolova, T.A., Dronova, T.Ya., Tolpeshta, I.I., 2005. The clay minerals in soils. Textbook. Tula. Grif\&Co. 336 p. [in Russian].

Verkhovtseva, N.V., Milanovskiy, E., Osipov, G., Kuzmina, N., Kubarev, E., 2004. Humus substance andmicrobial community of soil texture and ped fractions. Europ. Geosci. Union, 1st General Assembly, Nice, France. 